\title{
REGIONAL DELIMITATION OF THE ELBE RIVER BASIN BASED ON FLOOD SEASONALITY ANALYSIS
}

J. Chalušová, J . H la d ný, R. Č e k a l: Regional delimitation of the Elbe River basin based on flood seasonality analysis. - Geografie-Sborník CGS, 111, 3, pp. 247-259 (2006). - The study presents approaches that can be used for assessing flood seasonality in the Czech part of the Elbe River basin. For each of the selected gauging stations, a graphic-numerical method based on flood cumulative frequency curves was applied for identification of intervals, during which the probability of seasonal flood occurrence was high. The results were used for classification of the individual catchments into seven regions specific in terms of the flood seasonality.

KEY WORDS: floods - seasonality - region delimitation.

The presented research was funded by the Research Plan MSM 0021620831 "Geographical Systems and Risk Processes in Context of Global Changes and European Integration" of the Czech Ministry of Education and Research Project VaV-SM/2/57/05 "Long-term changes of river ecosystems in floodplains affected by extreme floods" of the Ministry of Environment of the Czech Republic which is fully appreciated by the authors.

\section{Introduction}

The knowledge of region delimitations according to seasonality occurrence of maximum flows has a particular importance for flood protection and identification of the flood risks in specific catchments, identification of flood mechanisms, development of frequency analysis for derivation of design floods, water management in reservoirs, and for improving general knowledge of flood regime in the landscape. Regional analysis is also frequently used for improvement of estimates of occurrence probability of extreme flood flows in localities where the flood observations are short compared to the estimated return periods of floods or in ungauged localities where the information from the similar observed catchments is used (Black, Werritty 1997; Burn 1997).

For the purpose of this study, the region is understood as aggregation of small catchments with a similar character of flow regime. The delimitation of the regions is based on approximate similarity of the characteristics inside individual regions and on differences in characteristics among the regions. The objective of this approach is to identify a group of catchments, which are sufficiently similar for ensuring the transfer of information on extreme flows across all localities grouped in the same region. Concerning the extreme flows, such defined entities should be at least quasi-homogenous.

As a measure of similarity of the different catchments, a characteristic of flood occurrence seasonality was chosen. Individual outputs of the seasonal analysis permit us to divide the relevant area of river basin, into the regions 


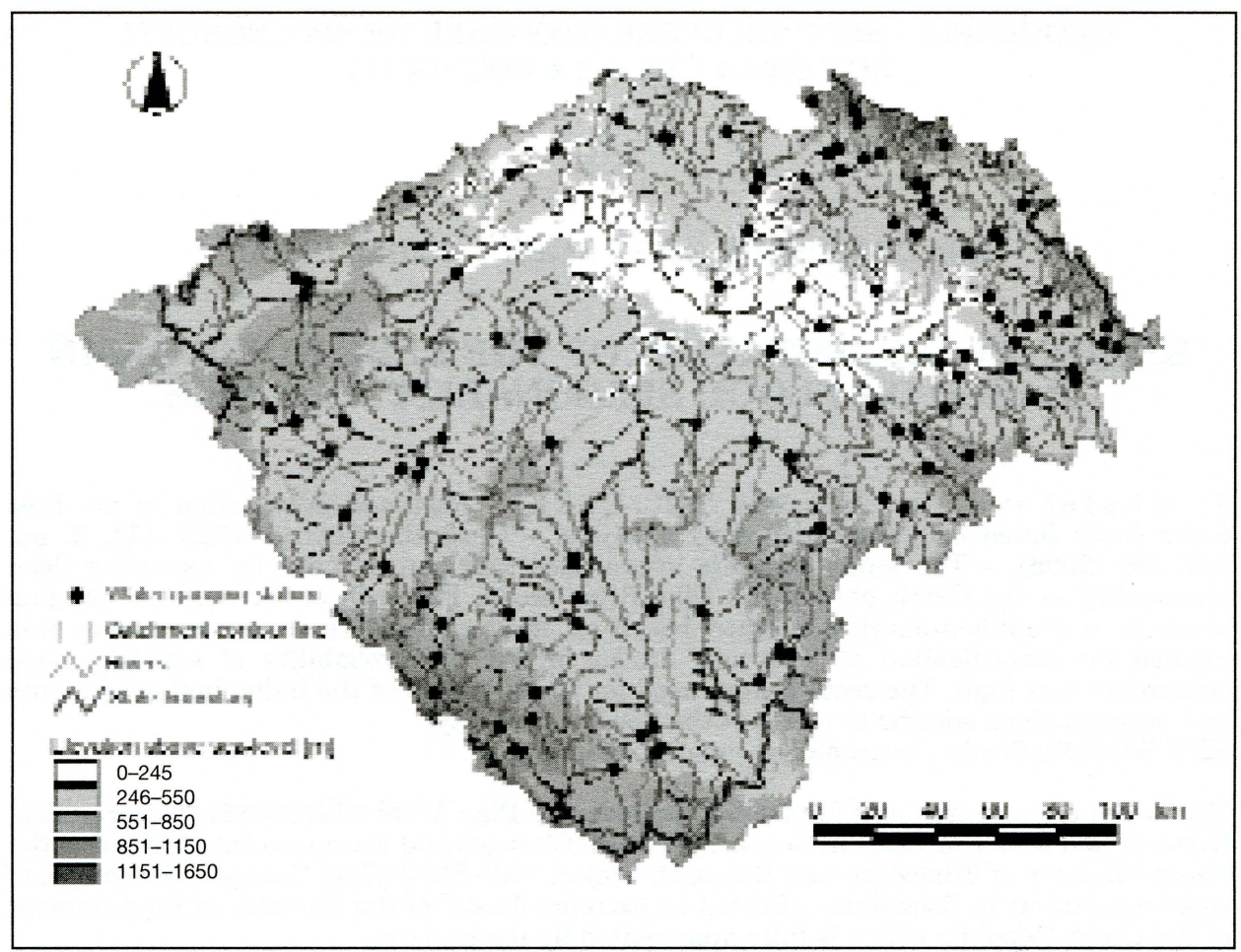

Fig. 1 - Selected stations in Czech Elbe River basin

with natural conditions predetermining the increased frequency of flood occurrence in the specific season of the year.

The research held previously on the observed area shows the differences as well as the similarities of selected catchments (Brádka 1967; Hladný 1971, 2001; Buchtele 1972; Kakos 1983, 1985; Vavruška 1989; Kašpárek 1999). In contrast to the previous studies, this study is not focused on an analysis of seasonal flood characteristics in selected catchments but it identifies hydrologically similar regions on the basis of similarity of seasonal characteristics of extreme flows occurrence. The methods that were used for analysis of seasonal flood occurrence include a polar diagram method, method of directional statistics and method of curves of cumulative frequency of flood occurrence.

The methods were applied for those gauging stations in the Czech part of Elbe River basin, whose flow regime is relatively natural.

\section{Collection and selection of data}

\subsection{Selection of representative gauging stations}

The database created for the purpose of this study contains the streamflow data observed by the selected gauging stations. The further criterion besides the natural streamflow regime was sufficient data quality. For this reason the 
gauging stations with significantly modified flow regime were not included into the database as well as the stations with incomplete or interrupted operating period.

The quality and quantity of available data differ across the regions of Czechia. In the area of the Elbe River basin, 441 gauging stations of state monitoring network were available. In the period from 1975 to 2000 , the uninterrupted series of flow data were available in 158 of them. With respect of the above selection criteria and with the aim to cover the entire area, 110 gauging stations were chosen. They include mainly stations on upper stretches on the streams. Catchment areas of these stations are relatively small (Fig. 1).

\subsection{Selection of hydrological data}

The use of maximum flows in individual months for the purpose of the region delimitation showed that such data could be insufficient because this approach does not take into account possible occurrence of two or more floods in the same month. For example, the two floods in July 1997 would be interpreted like a single event.

The study of the seasonal flood occurrence was therefore based on mean daily flow series available from the database of the Czech Hydrometeorological Institute (CHMI). Flow series of daily maxima, which would be more suitable for description of the flow regime, were not available. For each of the selected 110 gauging stations, the data from the period 1975-2000 were used.

\subsection{Selection of physic-geographical data}

For the catchments corresponding to the selected gauging stations, a database of the following parameters was prepared:

- catchment area

- mean catchment slope

- mean catchment altitude

- percentage of forested area

- thalweg length

- index of catchment shape

- slope orientation.

For catchment areas and thalweg lengths, data from CHMI were used. Mean catchment altitudes, mean catchment slopes and slope orientations were calculated in a Geographical Information System (GIS) by using a Digital Elevation Model with grid cell dimension of $100 \mathrm{~m} \times 100 \mathrm{~m}$.

\subsection{Selection of meteorological data}

The study applied meteorological data from rain gauging and climate stations of CHMI, involving snow cover height related to 15th March of the individual years (for estimation of snow storage before spring melting period) and annual precipitation series. All stations operating in the given reference period in the Elbe River basin on the Czech territory were used.

The mean precipitation totals over the catchments were calculated in GIS by using a method of orographic interpolation of precipitation (Sercl and Lett 2002), which was applied for precipitation data in the individual stations. The 
resulting system of grid cells $(1 \mathrm{~km} \mathrm{x} 1 \mathrm{~km})$ represents derived continual precipitation field for every year. Mean precipitation for the reference period 1975-2000 was calculated by averaging of precipitation fields in individual years.

This method was also applied for calculation of the mean height of the snow cover in March.

\section{Methods for analysis of seasonal flood occurrence}

The approach chosen to describe the spatial differences in seasonal flood occurrence in the Czech part of the Elbe River basin (covering an area of $51,394 \mathrm{~km}^{2}$ ) uses daily data and permits more accurate identification of the season period when probability of flood occurrence is high. The seasonal analysis was applied all gauging stations, whose data illustrate flow regime of the selected catchments.

Peaks over threshold (POT) method was used for analysis of flood flows which exceed the chosen threshold $Q_{B}$.

The method is defined by the expression (Todorovic and Zelenhasic 1970), where:

$$
\xi_{\nu}=\left\{\begin{array}{l}
0 \quad ; Q_{i} \leq Q_{B} \\
Q_{i}-Q_{B} ; Q_{i}>Q_{B}
\end{array}\right.
$$

$Q_{B}$ is the threshold flow,

$Q_{v}$ is a flow in time $\tau(v)$, and

$\zeta$ is the flow above the threshold in time $\tau(v)$.

For effective interpretation of seasonal information in the database, the chosen statistical method must be as accurate as possible. The paper shows results of a comparison of three mentioned methods that are applied for visualisation of seasonal distribution of flood occurrence. Each of the methods uses series of floods that exceed given threshold. The value of 1 year discharge was used as appropriate limit for this purpose.

\subsection{Method of polar diagrams}

The method of polar diagrams is based on graphical analysis of a rose diagram, whose radial vectors with angle unit of $30^{\circ}$ represent individual months of a year and are used for illustrating monthly occurrence frequencies or values of considered variable.

The rose diagrams were prepared for each of the gauging stations and the selected reference period. The lines that connect the individual values on the vectors form a polygon, which shows the seasonal distribution of the analysed variable and is typical for the specific station. If the frequencies of the occurrence could be uniform during the year, the shape of the diagram would form a regular dodecagon. However, the real distribution of a natural phenomenon is mostly typical by its irregularity. The values on the polar coordinates are more or less deviated for some periods of a year. Some periods are typical by the occurrence of extremes or remarkable deviation of the mean, while other periods show low probability of the flood occurrence (Fig. 2). 


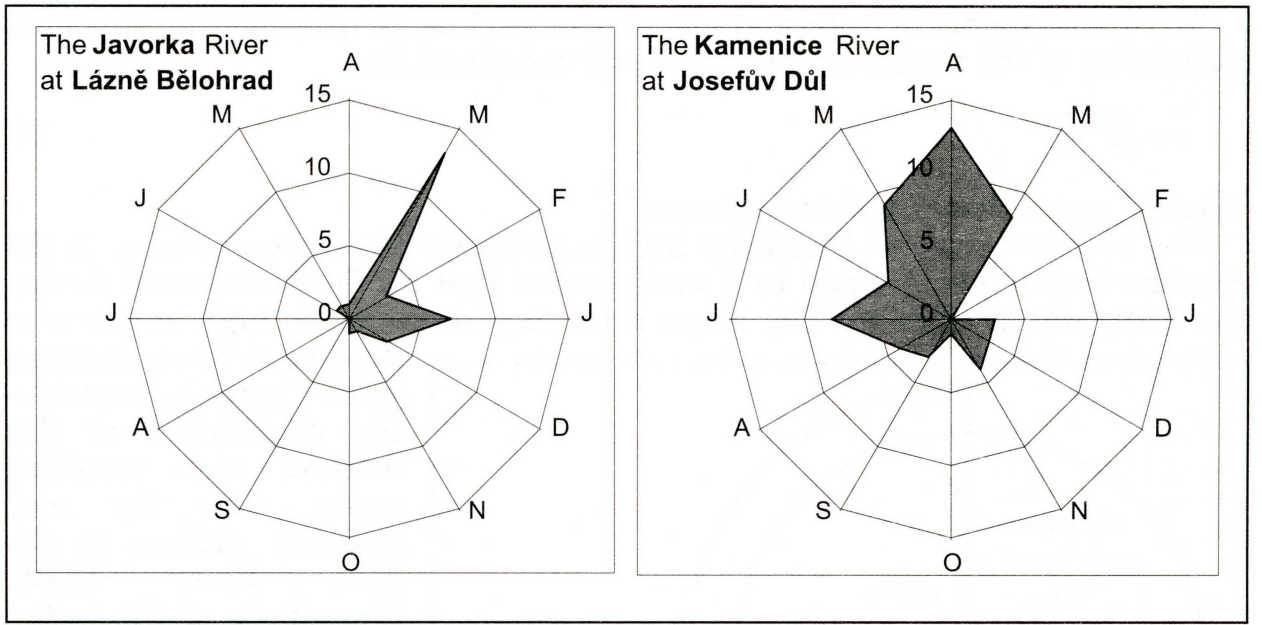

Fig. 2 - The method of polar diagrams used for analysis of flood occurrence at gauging stations Lázně Bělohrad on the Javorka River and Josefưv Důl on the Kamenice River in the period 1975-2000.

The polar diagram method has good information capability and they can easily be constructed. Low accuracy of derivation of maximum flow mean occurrence is its disadvantage.

\subsection{Method of directional statistics}

In this method, the dates of occurrence of the flood events are converted by using a polar coordinate system into relevant positions (angles) on a unite circle. In accordance with the mathematical convention, the beginning of the year (January $1^{\text {st }}$ ) is placed onto the most eastern point of the circle and individual seasons of the year form quadrants in anticlockwise direction (Mardia 1972; Bayliss, Jones 1993; Fisher 1993). The Julian date of the flood occurrence $i$ is converted into

$$
\phi_{i}=J D_{i}\left(\frac{2 \pi}{365}\right)
$$

where $\phi_{i}$ is an angle value (in radians) of the date of the occurrence of the flood event $i$.

$J D$ is Julian date.

Each date of flood occurrence can be interpreted as a vector (Fig. 3) given by angle $\phi_{i}$ and magnitude $m$, which represents the peak flow of the corresponding flood ( $m=1$ for maximum flood in selected gauging station). For series of $n$ floods, we can calculate coordinates $\bar{x}$ and $\bar{y}$ of mean date of flood occurrence $M D$ (Mean Day) in the selected gauging station as follows:

$$
\bar{x}=\frac{1}{n} \sum_{i=1}^{n} \cos \left(\phi_{i}\right) \quad \bar{y}=\frac{1}{n} \sum_{i=1}^{n} \sin \left(\phi_{i}\right)
$$

where $\bar{x}$ and $\bar{y}$ represent $x$ and $y$ coordinates of the mean date of flood occurrence in given catchment. 
As complementary information to the $M D$ it is possible to calculate variability of the flood occurrence, which is defined as:

$$
r=\sqrt{\bar{x}^{2}+\bar{y}^{2}}
$$

where $r$ represents the data variance.

The values $r$ close to 1 indicate high seasonality of flood occurrence in the catchment (the value equal to 1 would mean that all floods occurred during the same day of a year). The value close to zero indicates high variance of

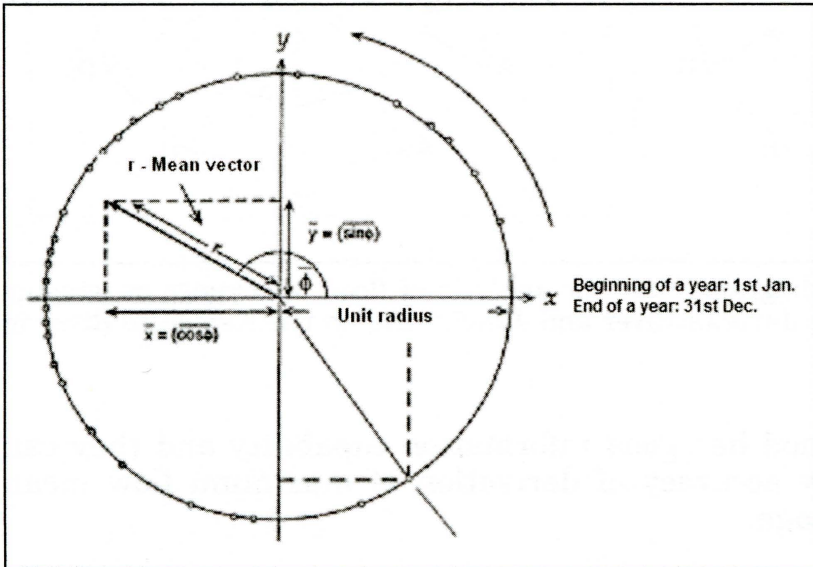

Fig. 3 - Application of the method of directional statistics for flood flow series (according to Black, Werritty 1997) flood occurrence during a year. Figure 4 illustrates the application of this method and resulting mean day for two gauging stations in the Elbe River basin. Magnitude of the radial vector determines the variance $r$.

The use of the method of directional statistics has two main advantages. First, it permits to express the information on seasonality occurrence of flood flows by a single value and, second, it permits to classify the studied localities by the mean date of maximum flow occurrence with accuracy of one day. Disadvantage of this method is in the error of the averaging because identical values of the mean can be obtained from different distributions of the data series.

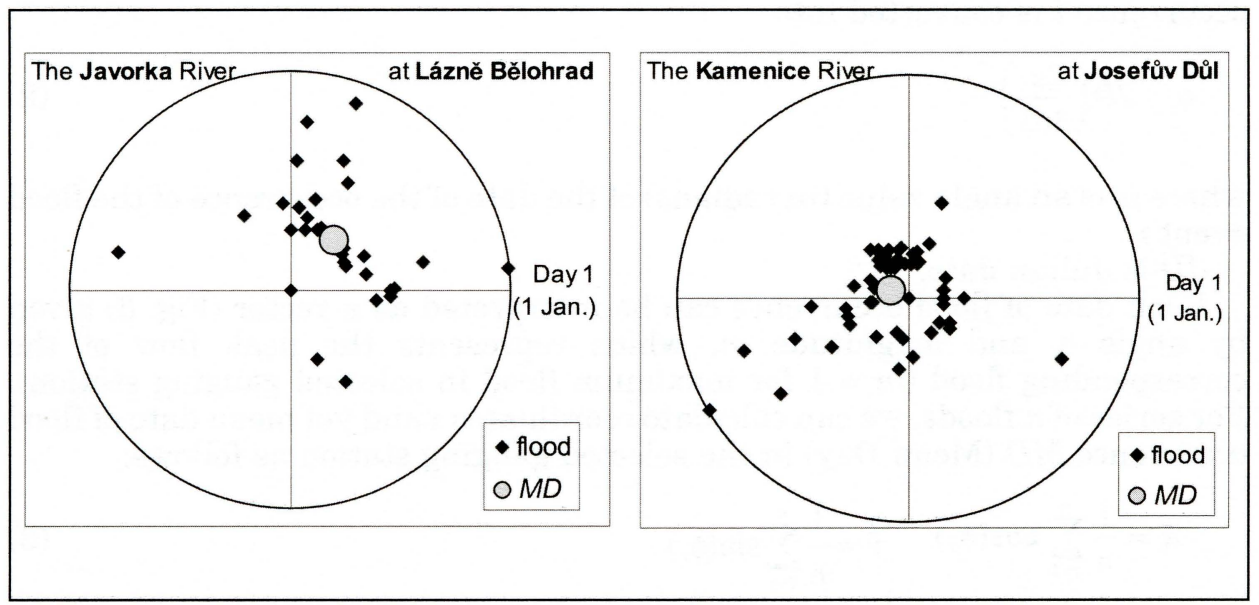

Fig. 4 - Method of directional statistics used for analysis of flood occurrence at gauging stations Lázně Bělohrad on the Javorka River and Josefưv Důl on the Kamenice River 


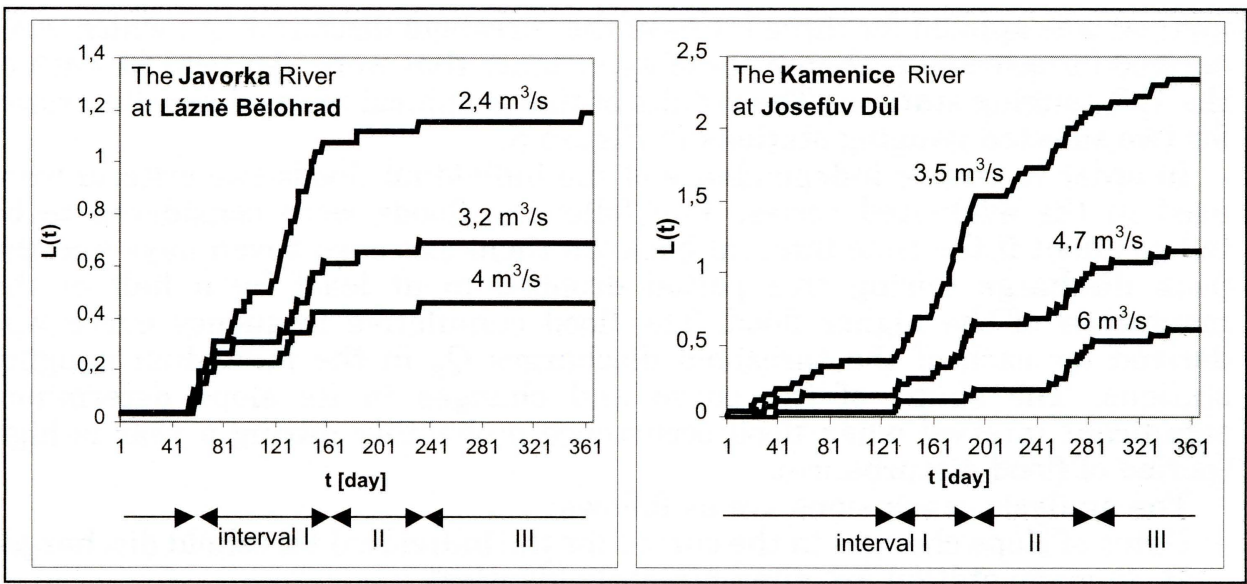

Fig. 5 - Method of flood cumulative frequency curves used for analysis of flood occurrence at gauging stations Lázně Bělohrad on the Javorka River and Josefưv Důl on the Kamenice River in the period 1975-2000

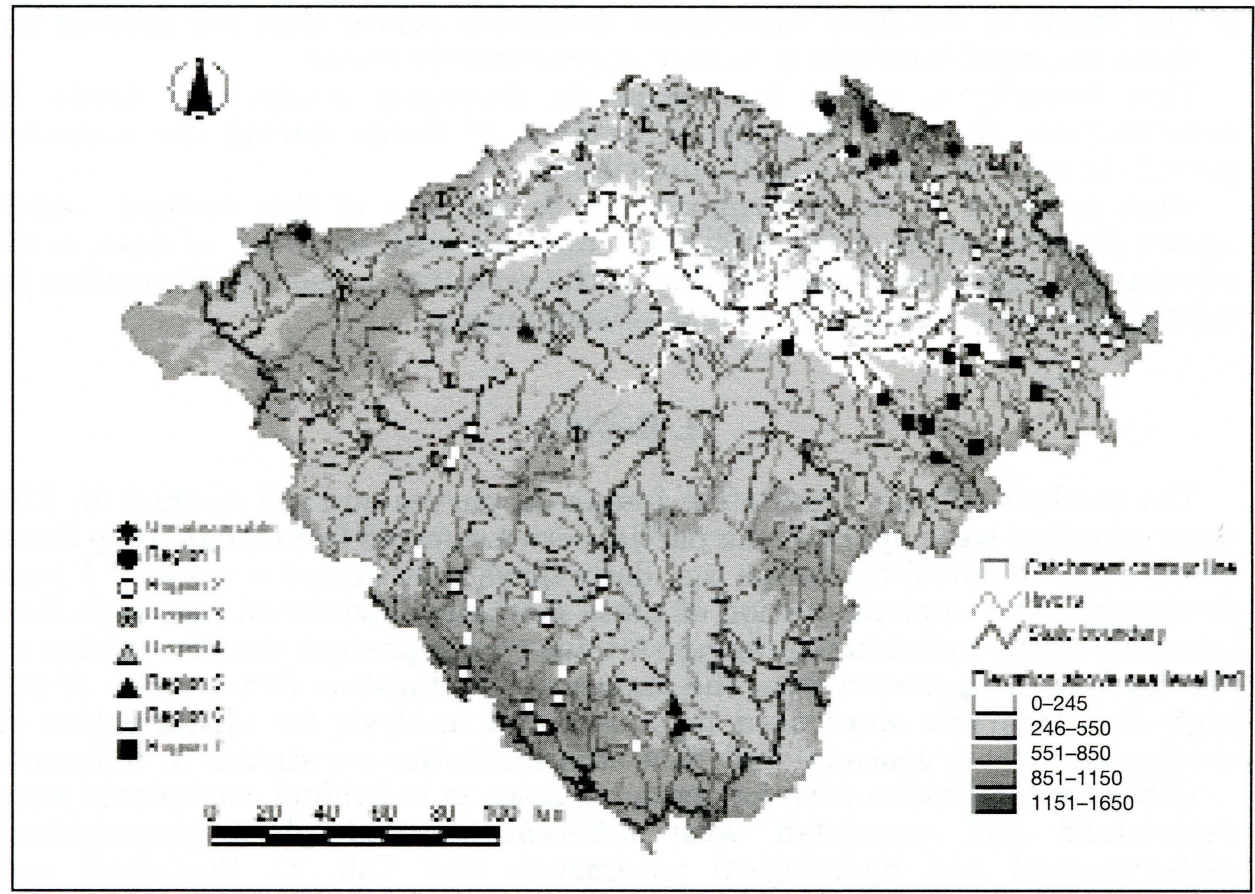

Fig. 6 - Map of derived regions according to seasonality of the flood occurrence

3.3 Method of flood cumulative frequency curves

The method is based on visualisation of mean numbers of floods $L(t)$ that exceeded given discharge $Q_{B}$ in time $t$. The values of variable $t$ range in time interval $(0, \mathrm{~T})$, which is relevant to a period of one year (Ouarda 1993). The 
method was applied for three levels of the threshold discharge $Q_{B}$, which were derived for selected probabilities of exceedance that were identical for each of the 110 gauging stations. The results of this graphical method are illustrated for two selected gauging stations in Figure 5.

In order to ensure independence of the individual floods two criteria were used in the evaluated series. Two following floods were considered to be independent if the time interval between them exceeded seven days and the peak discharge during this period dropped to at least by a half of the magnitude of the higher flood. The flood cumulative frequency curve was derived for each of the threshold discharges $Q_{B}$ in the individual gauging stations. The shape of the curve and changes in its slope determined significant interval when flood occurrence probability during a year is high (period of flood disturbance).

The analysis conclusions are as follows:

- Dates of slope changes in the curves for the individual threshold discharges $Q_{B}$ in given station are approximately identical.

- The slope changes divide a year into three intervals, whose durations are different and which differ also in flow magnitude (I - interval when probability of flood occurrence is high, II - transitional interval and III interval when probability of flood occurrence is low).

- The shape of the flood cumulative frequency curves that are derived for these seasonal intervals is mostly approximately linear.

This linearity is useful knowledge for frequency analysis of floods. It substantiates the fact that the occurrence of floods during the seasonal periods is approximately equally distributed.

High accuracy of the information on seasonality of this method, which allows determination of the high flow intervals with accuracy of days, is its advantage. Aggravated applicability of the resulting seasonal information in subsequent statistical analysis is its disadvantage.

\section{Results}

The method of flood cumulative frequency curves and the method for $M D$ determination were applied on a partial series selected from mean daily flows by using a threshold discharge (i.e. daily flows that exceed a value of 1 year discharge). The implementation of these methods determined also high flow intervals in the individual gauging stations that represent the flow regime in the catchment upstream from the stations. The duration delimitation of the high flow intervals were used in subsequent analysis for identification of catchments whose seasonal high flow characteristics are similar or different.

Other characteristics used for these purposes in individual catchments were determined and correlated with different selected physic-geographical, meteorological and hydrological parameters (see Tab. 1). Statistical and correlation analyses prove that $M D$ as well as scatterings of flooding occurrences $r$ show higher correlations in connection to the end of flood disturbance (period with higher probability of floods) than to its beginning. This reflects the properties of flood wave falling branches which correspond with basic hydraulic law defining depletion of water storage from catchments. The rising branches show greater differences between courses of summer and winter flood waves. It is also important if and how often the winter flood types are accompanied with occurrence of summer floods or if both types of floods exist in the catchments. 


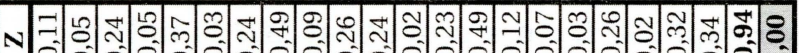

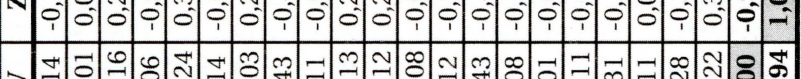

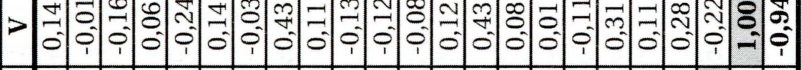

m

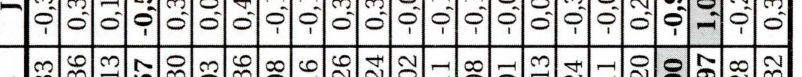

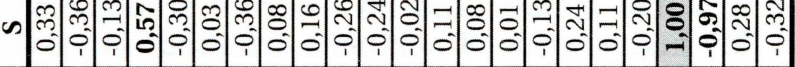

머위워

을

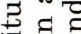

क

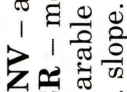

हี่

त्ञ

है, ซึ हृ

త్ర

동

पै

雨

牙

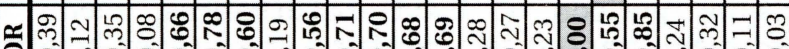

己ें छี

- 1 o

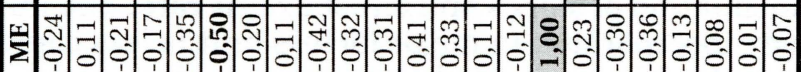

ฮิ อิ

을 $\frac{1}{2}$

$\boldsymbol{C}$

की

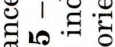

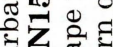

क

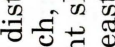

ช

$\circ \sum^{\mathbb{T}} \sum_{\nu}$

空

舟

4 记

ชु 0

1े

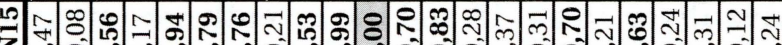

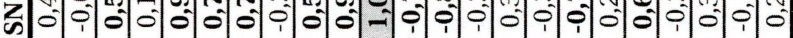

Z ऊ

ㄴำ

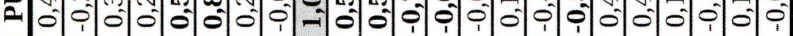

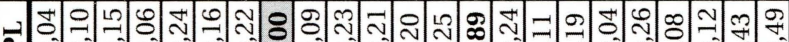
E

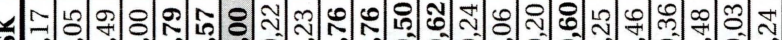

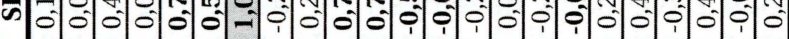
ᄂ 々 ๓ म) 인

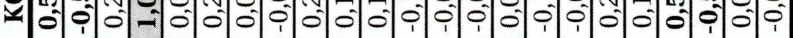

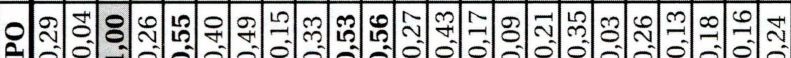

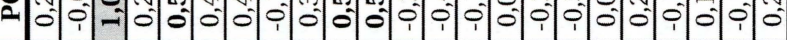

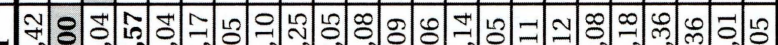

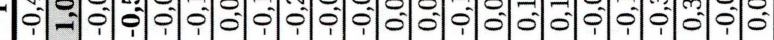
잉ㅎㅇำ $\Sigma=1$ O

I 1 .

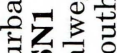

幽 需

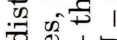

○ 17

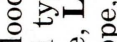

단

论

D 1 त्र

ヨص

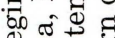

ญ

।

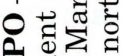

리 이

गु छे

के क्ष थी

क 1 ठ

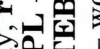

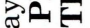

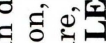

क्ष

ह द

1 구워

-

리 ్ㅣㅇ 
Evaluated physic-geographical factors prove that $M D$ is influenced by the altitude first of all. A distinct correlation is proved also to the snow cover height at the 15th March which is the decisive datum for estimation of snow storage in catchments before the spring melting. The altitude is significant even for extent of forests.

A tight direct proportional correlation of flood period ends was proved for catchments with north oriented slopes (and an indirect proportionality for south oriented slopes). The higher ratio of northern oriented slopes the later is the end of periods with higher probability of flood occurrence. This phenomenon can be explained with the longer period of snow melting.

Based on analyses of mutual relations between tested parameters the following factors were determined as the most significant: $M D$, the beginning and the end of seasonal periods of flood disturbances, mean annual precipitation height and mean annual temperature, snow cover height to the 15th March, altitude, inclination of slopes and forest extent rate. The influence of other factors is already incorporated in major factors or it is less significant.

The selected catchments were divided into seven regions based on similarity of major factors and on the application of cluster analysis in the GIS environment. Geographical division of regions illustrates Figure 6 . Individual regions can be considered as hydrologically homogeneous as to seasonality of flood occurrence.

The first region (north-eastern mountain ranges) includes 8 gauging stations, the second one (north-eastern foothills) 13, the third (uplands) 48, the fourth ("precipitation shadow" bellow the Krušné Mountains) 9, the fifth (areas affected with the Novohradské Mountains) 3, the sixth (the Sumava Mountains and the Otava River areas) 18 and the seventh one (areas affected with the Ždárské Mountains) 13 stations in question.

Other catchments, being without observation system, having influenced flow regime or laying in peripheral areas with unavailable flow data, were analysed with help of altitudes and distribution of average annual precipitation totals.

\section{Conclusion}

(1) A number of methods have been developed for assessing seasonality of flood regime in given region. With respect to various causal factors affecting flood occurrence, none of them however can universally be used as the best method. For the purposes of the objective of the study, which was to derive spatial patterns of seasonal distribution of flood flows, three methods were compared.

Polar diagrams provide good information, they are easily derivable but they are less accurate in terms of the results of statistical analysis. High transparency and reliability are advantages of the method of directional statistics, which determines a season of a year when the extreme flows are frequent. In addition, this approach can provide information on distribution of flood magnitudes of the individual events. The illustrated variability of the floods is also valuable information for assessments of the flood risks. On the other hand, its disadvantage is in the fact that the information on seasonal flood distribution that is concentrated into the averaged value can be insufficiently representative.

It was shown that the method based on flood cumulative frequency curves is relatively the most effective approach for derivation of suitable division 
of a year into three periods, which differ in terms of the high flow occurrence. Its advantage is in reliable detection of the beginning, end and duration of the probable high flow frequency interval, which is the most substantial information for the seasonal analysis.

(2) With respect to the objective of the study, which was to derive spatial patterns of seasonal distribution of flood flows, the method based on flood cumulative frequency curves provided the best results and was therefore applied. The results of the application of this method were used for the, region delimitation according to the flood flow seasonality in the Elbe River basin.

Majority of the detected high flow season interval showed good their correlation between onset, mean catchment altitude and long-term basin precipitation.

In terms of the similarity of the identified high flow periods, the individual water gauging stations and their basins were divided into seven hydrologically homogeneous regions.

\section{References:}

BAYLISS, A. C., JONES, R. C. (1993): Peaks over threshold flood database: Summary statistics and seasonality. Report No. 121. Institute of Hydrology, Wallingford, UK. 61 p.

BLACK, A. R., WERRITTY, A. (1997): Seasonality of flooding: a case study of North Britain. Journal of Hydrology, 195, pp. 1-25.

BRÁDKA, J. (1967): Meteorologické příčiny povodní ve Slezku (Meteorological causal factors of floods in Silesia). Meteorologiké zprávy, 20, ČHMÚ, Praha.

BUCHTELE, J. (1972): Kategorizace povodňového režimu na tocích vltavské kaskády (Categorisation of flood regimes on the rivers discharging into the Vltava Cascade of Reservoirs). Sborník prací HMÚ, 18, Praha.

BURN, D. H., ZRINJI, Z., KOWALCHUK, M. (1997): Regionalization of Catchments for Regional Flood Frequency Analysis. Journal of Hydrologic Engineering, pp. 76-82.

FISHER, N. I. (1993): Statistical Analysis of Circular Data. Cambridge University Press, Cambridge, UK.

HLADNÝ, J. (1971): K rajonizaci povodňových situací na území ČSR pro potřeby povodňové služby (To regionalisation of flood events on the territory of the Czech Republic for the purposes of the Flood Forecasting Service). Proceedings of papers of Hydrological Conference in Brno, Studia Geographica, 22, GÚ ČSAV, Brno.

HLADNÝ, J., CHALUŠOVÁ, J., VLASÁK, T. (2001): Hydrosynoptické přístupy $\mathrm{k}$ identifikaci povodňového mechanismu (Hydro-synoptic approaches to identification of flood development mechanisms). Acta Universitates Carolinae-Geographica, XXXVI, No. 2, UK v Praze, Praha.

KAKOS, V. (1983): Hydrometeorologický rozbor povodní na Vltavě v Praze za období 1873-1982 (Hydrometeorological analysis of floods on the Vltava River in Prague in 1873-1982). Meteorologické zprávy, 36, No. 6, ČHMÚ, Praha, pp. 171-181.

KAKOS, V. (1985): Hydrometeorologická analýza povodňových situací v povodí Labe (Hydrometeorological analysis of floods in the Elbe River basin). Meteorologické zprávy, 38, No. 5, CHMU, Praha, pp. 148-151.

KAŠPÁREK, L. a kol. (1999): Hodnocení modelování srážko-odtokových vlastností povodí (Assessment of modelling of rainfall-runoff attributes of catchments). VÚV T.G.M., Praha, $47 \mathrm{p}$.

MARDIA, K. V. (1972): Statistics of Directional Data. Academia Press, London, 38 p.

OUARDA, T. B. M. J., ASHKAR, F., EL-JABI, N. (1993): Peaks Over Threshold Model for Seasonal Flood Variations. Engineering Hydrology, USA, pp. 341-346.

ŠERCL, P., LETT, P. (2002): Výpočet rastru srážek v prostředí GIS s využitím ArcView Spatial Analyst (Calculation of precipitation grid using GIS and ArcView Spatial Analyst). User guide, version 2.0.1, ČHMÚ, OPV, Prague.

TODOROVIC, P., ZELENHASIC, E. (1970): A stochastic model for flood analysis. Water Resources Research, 6, No. 6, pp. 1641-1648. 
VAVRUŠKA, F. (1989): Meteorologické příčiny povodní na Otavě a Lužnici (Meteorological causal factors of floods on the Otava and Lužnice Rivers). Meteorologické zprávy, 42. ČHMÚ, Praha, pp. 111-115.

\section{Shrnu tí}

\section{REGIONALIZACE POVODÍ LABE NA ZÁKLADĚ SEZONÁLNÍ ANALÝZY VÝSKYTU POVODNÍ}

Poznatky o sezonalitě výskytu maximálních průtoků jsou jedním z důležitých podkladů především pro rajonizaci krajiny z hlediska jejîho zatížení povodňovým nebezpečím. Region se $\mathrm{v}$ těchto souvislostech chápe jako seskupení menších povodí, která mohou být považována za podobná z hlediska zvolených charakteristik odtokové odezvy. Vyhledání takového kvazi-homogenního shluku povodí $\mathrm{z}$ hlediska výskytu kulminace prủtokových vln bylo prováděno na základě korelační a shlukové analýzy př́činných klimatických, fyzicko-geografických a hydrologických faktorů v povodí českého Labe. Potřebné datové soubory byly odvozeny pro 110 vybraných vodoměrných stanic na menších povodích, které splňovaly podmínku neovlivněného anebo jen málo ovlivněného průtokového režimu (viz obr. 1). Rovněž nebyly zahrnuty stanice s přerušenou nebo neúplnou řadou měření v uvažováním referenčním období let 1975-2000. Základním problémem bylo určení spolehlivých reprezentativních sezonálních charakteristik.

Pro vyjádření charakteristik sezonality výskytu povodní existuje řada metod. V závislosti na různých př́činných vlivech působících při vzniku povodně však neexistuje žádná univerzálně nejlepší. Vzhledem ke stanovenému cíli, vyjádřit prostorové rozdíly sezonálního rozložení extrémních průtokům, byly porovnávány tři metody. U všech se pracuje $\mathrm{s}$ řadami průměrných denních průtoků nad hodnotou 1letého průtoku v souladu s obecnou definicí podle výrazu (1).

Metoda polárních grafů je založena na grafické analýze růžicového grafu, kde průvodiče odstupňované vždy po $30^{\circ}$ představují jednotlivé měsíce roku a jsou na nich vyneseny četnosti výskytu povodní v př́íslušném měsíci (viz obr. 2). Polární růžicové grafy mají dobrou vypovídací schopnost a jsou snadno sestrojitelné. Z hlediska statistického zpracování jsou však méně přesné.

Druhá metoda směrových statistik převádí datum výskytu kulminace povodní rovněž do polárního souřadnicového systému určením příslušné polohy v jednotkové kružnice. Úhlový převod $\phi_{i}$ se uskutečňuje podle vzorce (2) a velikost kulminačního průtoku $m$ je reprezentována jeho relativním podílem na hodnotě kulminace největší povodně ve sledovaném profilu, přičemž ta je rovna 1 (viz obr. 3). Pro soubor povodní (viz obr. 4) v daném referenčním období se určuje souřadnice průměrného dne výskytu povodní $M D$ (Mean Day) podle rovnice (3) a rozptyl výskytu povodňových případů $r$ podle rovnice (4). Přínosem metody směrových charakteristik je získání detailnějších informací o sezonalitě povodní a tím i větší spolehlivost, se kterou je vymezena část roku se zvýšeným výskytem extrémních průtoků. Navíc tento přístup umožňuje získat informace o sezonálním rozložení velikosti jednotlivých maximálních průtoků. Znázorněný rozptyl je proto cennou informací pro hodnocení zatížení povodí povodňovým nebezpečím. Naopak nevýhodou může být zatížení sezonálních informací známým nedostatkem průměrování, tzn., že téhož průměru lze dosáhnout z velmi rozdílného rozložení hodnot vstupních veličin.

Proto byla udržována ještě jako třetí metoda čar kumulativních četností výskytu povodní. Ćára se sestrojuje pro danou stanici postupným součtem kulminací (nad určitou prahovou hodnotou prủtoku), které byly zjištěny $\mathrm{v}$ jednotlivých dnech každého roku v uvažovaném referenčním období. Průběh čáry (časový počátek a konec výrazné změny sklonu čáry viz interval I v obr. 5, interval ustálené tendence - II a interval přechodový - III) vymezují signifikantní období se zvýšenou pravděpodobností rozvodnění (období povodňového neklidu) v každém uvažovaném období. Bylo ověřeno, že volba různé prahové hodnoty průtoku nemá vliv na určení počátku a konce povodňového neklidu, protože změna sklonu čáry kumulativních četností výskytu povodní nastává i při rozdílných mezních průtocích ve stejném dni. Spolehlivost určení délky trvání povodňového neklidu, což u sezonální analýzy stěžejní informace, je hlavní předností této metody.

Jako další charakteristiky pro tyto účely byly pro každé vybrané povodí určeny a korelovány mezi sebou určené fyzicko-geografické, meteorologické a hydrologické parametry, viz tabulka 1 . Statistická a korelační analýza prokázala, že $M D$ stejně jako rozptyl výskytu povodní vykazují vyšší korelaci ve vztahu ke konci povodňového neklidu než ve vztahu 
$\mathrm{k}$ jeho počátku. Je to dáno větší podobností poklesových větví průtokových vln, které se řídí jednotným hydraulickým zákonem pro vyčerpávání zásob vody v povodí. U vzestupných větví se odráží větší rozdíly mezi průběhem letních a zimních průtokových vln. Rozhoduje také zda a jak často jsou rozvodnění zimního typu doprovázeny letními výskyty povodní neboli zda v povodí existuje dvojí povodňový režim.

$\mathrm{Z}$ hlediska zkoumaných fyzicko-geografických faktorů je $M D$ nejvíce ovlivněn nadmořskou výškou povodí. Zřetelnou korelaci vykazuje i výška sněhu k 15. březnu, což je rozhodující datum pro odhad sněhových zásob v povodí před jarním táním. Rovněž plochy pokrytí lesem signifikantně souvisejí s nadmořskou výškou.

Úzká přímoúměrná vazba konce povodňového období byla prokázána i u povodí se severně orientovanými svahy (a naopak nepřímoúměrná s jižně orientovanými svahy). Č́m větší je podíl severně orientovaných svahů tím později $\mathrm{v}$ daném povodí končí období zvýšené pravděpodobnosti výskytu povodní. Tento vztah je zřejmě možné vysvětlit pozdější dobou odtávání sněhu na severních svazích.

$\mathrm{Na}$ základě analýzy vzájemných vztahů uvažovaných parametrů byly mezi majoritní faktory zařazeny následující veličiny: $M D$, počátek a konec sezonálního období povodňového neklidu, prưměrná roční výška, srážky a průměrná roční teplota, výška sněhové pokrývky ke dni 15.3., nadmořská výška, sklonitost svahů a lesnatost povodí. Vliv ostatních veličin byl bud’ implicitně již zaveden některým z majoritních faktorů anebo byl méně významný.

Vybraná povodí byla pak podle podobnosti, charakterizované majoritními faktory a dále pomocí aplikace metody shlukové analýzy v prostředí GIS, rozdělena do 7 oblastí. Geografické znázornění regionů ilustruje obr. 6. Výsledné regiony lze z hlediska sezonality výskytu povodní považovat přibližně za hydrologicky homogenní.

Do prvního regionu (severovýchodní pohoří) bylo zařazeno 8 stanic, do druhé 13 (severovýchodní podhưří), do třetího 48 (vrchoviny), do čtvrtého 9 (podkrušnohorský stín), do pátého 3 (oblast vlivu Novohradských hor), do šestého 18 (Pošumaví-Otavsko) a do sedmého 13 vodoměrných profilů (oblast vlivu Ždárských vrchů).

U dalších povodí, mimo těch vybraných, která nemají pozorování anebo mají ovlivněný odtokový režim či u sporných případů v okrajových oblastech regionů bylo přihlíženo k rozložení průměrných ročních srážkových úhrnů a $\mathrm{k}$ nadmořské výšce.

Obr. 1 - Vybrané vodoměrné stanice v povodí českého Labe

Obr. 2 - Metoda polárních grafů výskytu povodňových př́ípadů u profilů Lázně Bělohrad na Javorce a Josefův Důl na Kamenici

Obr. 3 - Aplikace metody směrových statistik na řadu dat povodňových průtoků

Obr. 4 - Metoda směrových statistik při analýze výskytu povodňových př́ipadů u profilů Lázně Bělohrad na Javorce a Josefưv Důl na Kamenici

Obr. 5 - Metoda čar kumulativních četností výskytu povodňových případů u profilů Lázně Bělohrad na Javorce a Josefův Důl na Kamenici

Obr. 6 - Mapa odvozených regionů podle sezonality výskytu povodní

(Authors are with Czech Hydrometeorological Institut, Na Šabatce 17, 14306 Praha 4, Komořany; Czechia; e-mail: chalus.spol@volny.cz,hladny@chmi.cz,cekal@chmi.cz.)

Arrived to the editorial board on August 28, 2006 